\title{
PROGRAMA DE INTEGRAÇÃO SAÚDE COMUNIDADE EM UMA ESCOLA PÚBLICA DE MANAUS: RELATO DE EXPERIÊNCIA.
}

\author{
Francimar Oliveira de Jesus
}

Centro Universitário do Norte (UNINORTE)

DOI: $10.47094 /$ ICONRES.2021/12

Introdução: O Programa de Integração Saúde Comunidade (PISC), é uma disciplina do curso de enfermagem que visa proporcionar ao aluno uma integração à comunidade por meio de ações multiprofissionais, reunindo vários cursos da saúde para a prestação de serviços que gerem resultados positivos ao público assistido. Objetivo: Relatar a experiência de uma acadêmica de enfermagem ao participar de uma ação voltada para adolescentes do ensino médio em uma escola publica de Manaus. Métodos: Foram realizadas entrevistas semiestruturadas, com alunos do $1^{\circ}$ ao $3^{\circ}$ ano do ensino médio, com a finalidade de levantar as principais deficiências da instituição, como: falta de professores, merenda escolar e estrutura. Em seguida foram aplicados questionários a respeito da deficiência por parte dos alunos em relação a saúde do adolescente, como por exemplo, gravidez na adolescência, uso de preservativos e IST's. Resultados: Após análise das entrevistas ficou constatado que o maior problema em relação a Instituição era a falta de professores e da matéria Educação Física. Em relação aos alunos a maior deficiência de informação foi sobre a falta de educação sexual na escola. Diante disto, separou-se um dia da semana para a realização de atividades que suprissem essas necessidades, os alunos do curso de Enfermagem realizaram uma palestra sobre educação sexual abordando os temas gravidez na adolescência, uso de preservativos e infecções sexualmente transmissíveis. Os alunos de Educação Física e Nutrição criaram uma gincana na quadra poliesportiva da escola com premiação aos ganhadores. Conclusões: A partir destas ações tornou-se possível observar a necessidade de atividades voltadas ao público adolescente nas escolas e principalmente sobre a necessidade de ouvilos, dando assim o primeiro passo para a realização da educação em saúde.

Palavras-chave: Educação em Saúde. Multiprofissional. Enfermagem.

Área Temática: Educação em Saúde. 